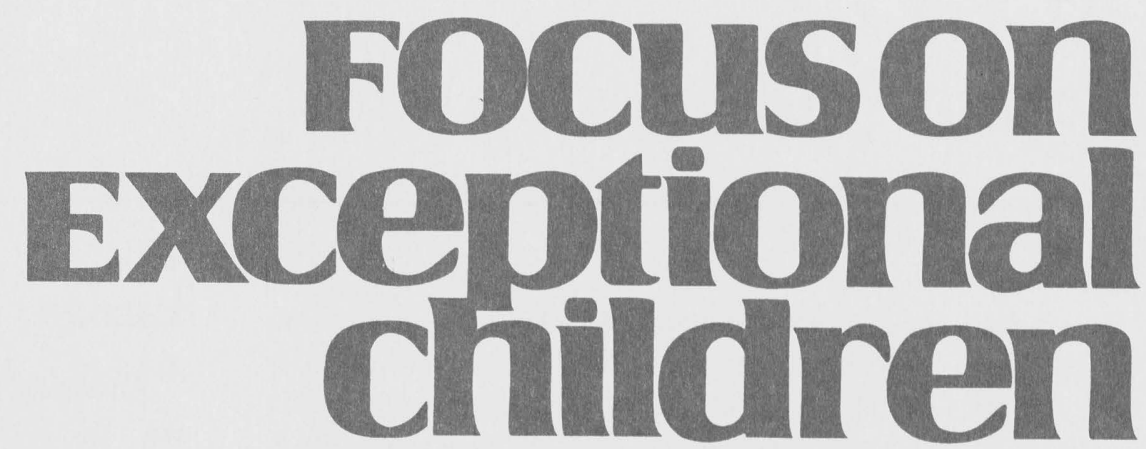

\title{
Leadership and the Gifted
}

\section{Frances A. Karnes and Suzanne M. Bean}

A current examination of the status of society brings visions of international discord, AIDS, violence, drug abuse, and interpersonal conflicts of all types. Although the growth of pluralism, ethnicity, and cultural pride has been positive for society, various forms of oppression and suppression still exist. The interdependence of all human systems is inevitable. The challenge of more effective human interaction and more creative problem solving is salient. The need for more dynamic leadership is critical to the success and advancement of our human existence.

Although the expression "a lack of leadership" points to this crisis of leadership, the concept of leadership remains misunderstood. Further, the most effective process for developing good leaders is still debated by educators, business persons, and other interested members of society.

If we as a society wish to be more proactive in our efforts to address the issues and dilemmas of today, a more hyperopic view must be taken. The long-range goals of the cause must be served. More serious consideration must be given to leadership development, and more purposeful endeavors must be created to cultivate bright, young leaders.

Leadership remains one of the categories of giftedness in the federal and in many state definitions. Nevertheless, the need for more study and action of leadership is imperative. Well designed effectiveness studies of existing programs for leadership development are sorely needed, and more substantive, innovative programs for young gifted leaders should be created and attempted.

\section{DEFINING LEADERSHIP}

The body of literature on leadership is replete with definitions ranging from earlier, single-trait definitions to more recent, complex, person-process-situation interactive perspectives. The word leadership continues to denote different things to different people. Defining leadership is complicated further by the difficulty of determining who is a leader and when an act of leadership has occurred. Leadership is often a range of experiences in the life of a person, which suggests the changing nature of the elusive concept.

Dr. Karnes is a professor of special education and the director of the Center for Gifted Studies at the University of Southern Mississippi. Dr. Bean is an associate professor of education and director of the Mississippi Governor's School at the Mississippi University for Women. 
Barr and Barr (1989) described a leader in the following way:

\begin{abstract}
A leader sees the vision, communicates its possibilities, believes in its achievement, inspires others to contribute their best, motivates others to want to belong, stretches and pushes people, and demonstrates the confidence of victorious achievement of the vision. (p. 21)
\end{abstract}

Gardner (1990) defined leadership as
... the process of persuasion or example by which an individual (or leadership team) induces a group to pur- sue objectives held by the leader or shared by the leader and his or her followers. (p. 1)
Leadership has been defined by Clark and Clark (1994) as

\begin{abstract}
... an activity or set of activities, observable to others, that occurs in a group, organization or institution involving a leader and followers who willingly subscribe to common purposes and work together to achieve them. (p. 19)
\end{abstract}

Many similarities exist in the definitions of leadership; almost every definition includes the concepts of leaders, followers, and the interaction of the two. The differences in definitions often reflect the writer's basic philosophical orientation.

\section{Focuson
Exceptional
children \\ ISSN $0015-511 \mathrm{X}$}

FOCUS ON EXCEPTIONAL CHILDREN (USPS 203-360) is published monthly except June, July, and August as a service to teachers, special educators, curriculum specialists, administrators, and those concerned with the special education of exceptional children. This publication is annotated and indexed by the ERIC Clearinghouse on Handicapped and Gifted Children for publication in the monthly Current Index to Journals in Education (CIJE) and the quarterly index, Exceptional Children Education Resources (ECER). The full text of Focus on Exceptional Children is also available in the electronic versions of the Education Index. It is also available in microfilm from Xerox University Microfilms, Ann Arbor, MI. Subscription rates: Individual, \$30 per year; institutions, $\$ 40$ per year. Copyright (C) 1996, Love Publishing Company. All rights reserved. Reproduction in whole or part without written permission is prohibited. Printed in the United States of America. Second class postage is paid at Denver, Colorado. POSTMASTER: Send address changes to:

$$
\begin{gathered}
\text { Love Publishing Company } \\
\text { Executive and Editorial Office } \\
\text { P.O. Box } 22353 \\
\text { Denver, Colorado } 80222 \\
\text { Telephone (303) } 757-2579
\end{gathered}
$$

Edward L. Meyen University of Kansas

Richard J. Whelan

University of Kansas Medical Center
Glenn A. Vergason Georgia State University

Kristin Kennedy Assistant Editor

\section{THEORIES OF LEADERSHIP}

Analysis of the evolution of theories of leadership reveals several distinct phases (Schriesheim, Tolliver, \& Behling, 1984). The original trait conception of leadership was based on the assumption that leaders possessed universal characteristics that made them leaders. These characteristics were considered fixed, inborn, and applicable across all situations. The "great man theory" advocated by Galton (1869) represents this idea. Several early researchers (Mumford, 1909; Murphy, 1941; Person, 1928) explained the emergence of great leaders as a result of time, place, and circumstance. Later, Fiedler (1961) emphasized the "leadership effectiveness traits" as qualities needed to perform well as a leader rather than those needed to become one.

Many situational elements now are recognized as influencing the emergence of leadership. Among them are the nature of the task, knowledge of the task, motivation of the followers, availability of human and material resources, the leaders' attributes, and quality of leader-follower relations (Calder, 1977; Jacobs, 1970; Lord, De Vader, \& Alliger, 1986; Rush, Thomas, \& Lord, 1977; Vroom \& Yetton, 1974). These ideas initiated the connection between traits/attributes and behavior/performance. During this phase, leadership was considered a changeable entity.

The "situational leadership theory" inspired further analysis of the relationship among leader behaviors, followers' satisfaction and performance, and the situation of the leadership experiences (Blake \& Mouton, 1985; Hersey \& Blanchard, 1982). The work of Stogdill (1974) and Bass (1981) supports the notion that leadership effectiveness is highly dependent on the relationship between leader characteristics and the demands of specific situations.

The past decade has seen an interest in "transactional and transformational leadership theories" (Bennis \& Nanus, 1985; Hollander \& Offerman, 1990; Yammarino \& Bass, 1990). The basic difference in these two models is in the process by which the leader is thought to motivate followers. Transactional leaders motivate through contingency rewards and negative feedback. For example, a transactional leader may evoke an increase in productivity by offering a merit pay plan. In contrast, transformational leaders inspire performance beyond ordinary expectations as they create a sense of mission and encourage new ways of thinking.

\section{CURRENT RESEARCH}

A current examination of research in the area of leadership shows that the majority of work relates to adult leaders. Studies focusing on leadership and youth are increasing, which may indicate society's recognition of the need to direct more attention to early development of leadership potential. 


\section{Studies of Gender Differences}

The studies pertaining to leadership and gender in youth reveal a variety of differences. Using the High School Personality Questionnaire (HSPQ), the personality characteristics of student leaders with above-average to superior levels of intelligence in grades 6 through 11 were studied. Significant differences were found to favor girls on emotional stability, dominance, and the secondary factor of independence (Karnes \& D'Illio, 1989b).

Sex-role stereotyping of leadership roles has been investigated with student leaders in grades 6 through 11 and elementary-level intellectually gifted youth. The girls in both groups perceived most of the leadership roles to be suitable for either gender, whereas the boys held more traditional stereotypical views (Karnes \& D'Illio, 1989a, 1990).

The perceptions of leadership held by student leaders and females also have been investigated. Karnes and McGinnis (1995) replicated and expanded a study conducted by Meriweather and Karnes (1989) and found that the views held by both groups were positive. In investigating the perceptions of leadership held by secondary-level, female student leaders, it was found that they did not think that popularity is a prerequisite for leadership, that men make better leaders, that leaders must make good grades, that leaders must be wealthy, or that leaders must come from large urban areas (Karnes, Bean, \& McGinnis, 1994/95).

\section{Relationship Between Leadership and Giftedness}

Many parallels exist between the characteristics used to define an effective leader and the characteristics used to describe a gifted individual. Effective leaders and gifted students are highly verbal, socially sensitive, visionary, problem solvers, critical thinkers, creative, initiators, responsible, and flexible. Although the need for more effective leaders is clear, and gifted students typically possess the characteristics to become effective leaders, the development of leadership skills in gifted youth is often neglected.

Much of the research on leadership and giftedness suggests a positive relationship between the two concepts. Terman's (1925) classic study of the gifted revealed that gifted students were often the leaders in school. Hollingworth's (1926) research indicated that, among a group of children with average intelligence, the IQ of leaders was likely to fall between 115 and 130. Schakel (1984) indicated that, in comparison with nongifted students, gifted students could be characterized as visionary leaders, whereas nongifted students seemed to be organizational leaders.

Using the HSPQ with students attending a self-contained high school for the intellectually gifted, Karnes, Chauvin, and Trant (1984) found that the HSPQ failed to discriminate between individuals who held an "elected" leadership position and those who did not. Elected leaders, however, tended to be more tender-minded (sensitive, overprotected, intuitive, tense, driven, group-dependent, and conscientious) than the nonelected group. In addition, females scored significantly higher than males on excitability, and males scored significantly higher than females on sensitivity (Karnes, Chauvin, \& Trant, 1984).

\section{Psychological Type}

Recent studies have shown that psychological type can be a good predictor of leadership style and behavior (Barr \& Barr, 1989; Campbell \& Velsor, 1985; Lawrence, 1982; McCaulley et al., 1990; Myers \& Myers, 1980). Alvino (1989) reviewed data collected using the Myers-Briggs Type Indicator with gifted students and young adults. His analysis revealed that high school student leaders who were not necessarily designated as gifted fell predominantly into a group that could be described as analytical managers of facts and details, practical organizers, imaginative harmonizers of people, and warmly enthusiastic planners of change. Leaders in student government activities fell predominantly into a group that could be described as independent, enthusiastic, intuitive, aggressive, and innovative.

A study conducted by Meriweather (1989), involving 176 intellectually gifted students in grades $6-8$, examined the relationship between leadership potential and the variables of birth order, elected leadership position(s), gender, grade level, participation in extracurricular activities, the dimensions of psychological type, and a teacher rating of leadership characteristics. A significant relationship was found between the combined group of variables and the leadership potential of the gifted students in this study. Each of the variables of the extroversion/introversion, the thinking/feeling, and the judging/perceiving dimensions of psychological type was found to have the independent power to discriminate significantly between students with high and non-high leadership potential, whereas the other variables did not discriminate between these two groups.

\section{Leadership Education and Training}

Other studies have focused on various dimensions of the study of leadership development in gifted youth. Feldhusen and Kennedy (1988) concluded that leadership skills and theory should be explicit goals in the education of gifted youth and that part of a leadership education program should explore the interaction of leadership talent with changes emerging in society, thinking skills, and the study of the major concepts, trends, and issues of the world. Research by Lindsay (1988) indicated a need to connect leadership education and moral education and to provide leadership experiences that are morally educative. A study conducted by Myers, Slavin, and Southern (1990) examined the relationship between lead- 
ership styles of secondary gifted students and various tasks demands. The results of the project revealed a need to place less emphasis on the leader and more emphasis on the task.

Smith, Smith, and Barnette (1991) described the impact of a leadership training program for gifted adolescent students. As a result of the program, changes were demonstrated in the students' willingness to respond to group members, ability to influence others, verbal assertiveness, decision making, selfassuredness, and several other group dynamic skills.

Ramey's (1991) work on gifted leadership noted that many gifted leaders find that their advanced perception, skill, and insight isolate them from their followers and others in their lives. He further stated that gifted leaders who are able to realize their own human potential fully are those who are successful at integrating many dimensions of life, including personal integrity, community investment, and vocational integrity.

\section{Rural and Suburban Comparison}

Abel and Karnes (1993) compared rural and suburban gifted high school students to determine differences in selfperceived leadership potential as indicated on the Leadership Strengths Indicator. No significant differences were found, but leadership training was recommended for both groups.

Unique parallels also exist between the definitions of giftedness and leadership. Definitions in both areas are expanding, becoming more inclusive, and considering cultural and situational factors. The identification and assessment procedures for both giftedness and leadership have developed to reflect the complexity and multidimensionality of the concepts.

\section{Leadership, Intelligence, and Social Behaviors}

Leadership also has been studied with student leaders having above-average to superior intelligence. The correlations of leadership skills and self-actualization, using the Leadership Skills Inventory (LSI) (Karnes \& Chauvin, 1985a) and the Reflections of Self by Youth (ROSY) (Schatz, 1981) with student leaders in grades 6 through 11, were found to be significant (Karnes, Deason, \& D'Illio, 1993).

Student leaders in grades 6 through 11 and their parents' perceptions of their children's social skills were studied using the Social Preference Survey Schedule. Student leaders perceived themselves as exhibiting more positive social behaviors than did their parents. Mothers perceived their children as more socially skillful than did their fathers (D'Illio \& Karnes, 1992).

Using the Leadership Strengths Indicator (Ellis, 1990) with disadvantaged youth ages 10 to 15, Riley and Karnes (1994a) found that the students' scores fell within the normal range. A significant difference favoring boys was found in the scale "High Level Participator in Group Activities." Slight nonsignificant differences were found between the scales "Enjoys Group Activities," "Journalistic," and "Courageous."
The same measure was administered to intellectually gifted students in grades 4 through 6 , and significant differences were found favoring girls on two scales, "Sympathetic" and "Conscientious," and the total score (Riley \& Karnes, 1994b). Intellectually gifted students in grades 6 though 12 in suburban and rural settings also were administered the same instruments, and no significant differences were found (Abel \& Karnes, 1993).

\section{Extracurricular Activities}

Several studies indicated that participation in extracurricular/community activities provides unique opportunities for students to belong and contribute to a group, as well as to experience success (Bass, 1981; Bennett, 1986; McNamara et al., 1985; Stogdill, 1974). These studies suggest that extracurricular activities may be more highly correlated with adult leadership than is academic achievement.

\section{CHARACTERISTICS AND IDENTIFICATION}

Of all of the dimensions of giftedness set forth in the various state and federal definitions, leadership is the most neglected area. Although teachers, administrators, parents, and other concerned adults interested in gifted education perceive bright youth as being the future leaders at local, state, national, and international levels, little has been or is being done to screen, identify, and instruct these youth appropriately for true positions of leadership. Foster and Silverman (1988) stated that schools must go beyond educating the gifted for followship and must become involved in understanding the fundamentals of leadership and incorporating it into the school curriculum. Lindsay (1988) said that leadership is the most controversial and neglected area in gifted education. Florey and Dorf (1986) stated that few gifted programs incorporate leadership into the curriculum for the gifted.

The characteristics of the gifted make them excellent candidates as leaders. These include the desire to be challenged, creative problem-solving ability, critical reasoning skills, persistence, initiative, sensitivity, self-sufficiency, the ability to see new relationships, and enthusiasm (Black, 1984; Chauvin \& Karnes, 1983; Plowman, 1981).

Identifying students for leadership training is a complex task. Various methods of screening and identification have been offered. Conradie (1984) urged that leadership potential be identified early and that it also be continuous. He stated that, as children develop, social changes and leadership ability may emerge. Three methods of identification were offered by Olivero (1977):

1. Parents (good indicators of leadership potential in young children)

2. Sociometric devices (for early adolescents)

3. Self-esteem inventories (for upper secondary youth).

Friedman, Friedman, and Van Dyke (1984) found self-nomination to be the single most effective method of identifying 
leadership potential in students; however, they supported the use of multiple sources of information as necessary for identifying gifted adolescents with leadership ability. Sisk (1984) and Addison (1985) also reported various methods as being useful. Collectively, their suggestions provide a comprehensive listing of nominations and ratings by peers, teachers, self, and community group members; observations of group activities; interviews; personality tests; biographical information on past leadership experiences; and leadership-style instruments.

\section{LEADERSHIP INSTRUMENTS}

Karnes and Meriweather-Bean (1991) characterized the status of screening and identification instruments in leadership for elementary and secondary youth as limited and in its infancy. The same seems to be true several years later. Measurements with standardization data based on validity and reliability are limited in number:

- Leadership Characteristics (Part IV) of the Scales for Rating Behavioral Characteristics of Superior Students (SRBCSS) (Renzulli et al., 1976)

- Rating Scale for Leadership (Roets, 1986b)

- High School Personality Questionnaire (Cattell, Cattell, \& Johns, 1984)

- Myers-Briggs Type Indicator (Myers \& McCaulley, 1985)

- Murphy-Meisgeier Type Indicator for Children (Meisgeier \& Murphy, 1987)

- Gifted Education Scale (McCarney, 1987)

- Student Talent and Risk Profile (Institute for Behavioral Research in Creativity, 1990)

- Khatena-Morse Multitalent Perception Inventory (Khatena \& Morse, 1994)

- Leadership-A Skill and Behavior Scale (Sisk \& Rosselli)

- Eby Gifted Behavior Index (Eby, 1989)

All the instruments vary in several aspects including grades and/or ages, number of items specific to leadership, response modes, scoring procedures, interpretation, and scores rendered.

Two additional standardized measures are commercially available: the Leadership Skills Inventory (Karnes \& Chauvin, 1985a) and the Leadership Strengths Indicator (Ellis, 1990). They have been designed for purposes other than screening and identification. The former was developed to be a diagnostic/prescriptive measure for instruction in leadership, and the latter was designed to serve as a basis for discussion on the topics of leaders and leadership by counselors and teachers.

\section{Scales for Rating Behavioral Characteristics of Superior Students}

The Scales for Rating Behavioral Characteristics of Superior Students (SRBCSS) (Renzulli et al., 1976) were designed to assist teachers in their nominations of students for specialized programs for the gifted and talented. The original scales consisted of four rating areas or components: learning, motivation, creativity, and leadership. A criterion of the scales accepted early in the development process was that, for a specific observable characteristic to be included in the instrument, at least three separate studies in the literature had to have specified the importance of that characteristic. A variety of school districts offering programs for gifted and talented youth were involved in the first experimental edition. Many suggestions of counselors, teachers, and other school personnel were incorporated.

Validity and reliability studies were undertaken on all four scales. Part IV, Leadership Characteristics, was validated by comparing teachers' and peers' ratings through sociometric techniques (Hartman, 1969). The correlations were high for teachers and fourth, fifth, and sixth grade students' ratings (Renzulli et al., 1976). By correlating the individual items with the total leadership ratings, the internal consistency of the leadership scale was verified by Renzulli et al.

Further studies included investigation of the factor-analytical structure of the SRBCSS (Burke, Harworth, \& Ware, 1982). These studies found that the leadership characteristics assessed many behavioral characteristics that typify leadership but concluded that they were descriptive of the type of leader who conforms and adapts to traditional expectations in a school setting. A study conducted with Mexican-American gifted students indicated that the instrument could be useful as an identification and research instrument for that group of students. Argulewicz, Elliott, and Hall (1982) and Elliott and Argulewicz (1983) strongly supported the use of the SRBCSS as a supplementary measure to be employed with other instruments in the identification of the gifted.

In addition, the reviews of Rust and Argulewicz gave positive support to the use of the SRBCSS. The two reviewers cautioned, in the Ninth Mental Measurement Yearbook (Buros, 1985), that the major drawback of the scales is the unavailability of published norms. The authors of the instrument, based on their assumption that student groups would vary widely, did not establish norms or exact scores for the gifted. The authors currently are revising the SRBCSS.

\section{Rating Scale for Leadership}

Roets (1986b) designed a self-rating instrument, the Rating Scale for Leadership, for students in grades 5 through 12 with the approximate ages of 10 through 18 . The instrument contains 26 items rated on a 5-point scale. The ratings are as follows: almost always, quite often, sometimes, not very often, and never. The instrument was administered to 1,057 youth living in the continental limits of the United States in both public and private schools. The validity was established by administering to 631 students in the standardization group two other measures of leadership with correlations of $r=.71$ 
and .77, respectively. The Spearman-Brown split-half formula was employed to establish reliability, and correlation for the total sample was $r=.85$. Further investigation of reliability of the measure with the leadership scale of the SRBCSS indicated a correlation of $r=.55$.

\section{High School Personality Questionnaire}

The Leadership Potential Score (Cattell et al., 1984) can be obtained from the High School Personality Questionnaire (HSPQ) (Cattell et al., 1984). Fourteen bipolar traits of personality are assessed: warmth, intelligence, emotional stability, excitability, dominance, enthusiasm, conformity, boldness, sensitivity, withdrawal, apprehension, self-sufficiency, self-discipline, and tension. The questionnaire, for students ranging in age from 12 to 18 , was designed and standardized to be a self-rating instrument. It may be given individually or in groups. The 142-item instrument requires approximately 45 to 60 minutes to administer. Numerous studies attesting to validity and reliability of the instrument with a variety of youth samples are described in the manual (Cattell et al., 1984).

The LPS is predicted from the HSPQ by an equation derived empirically by combining scores on the 14 primary scales using a specific formula (Johns, 1984). The LPS has been employed in several studies with intellectually gifted, creative, and leadership students. The mean scores of the subjects in each study were above those of the norm group (Karnes, Chauvin, \& Trant, 1984; Karnes, Chauvin, \& Trant, 1985; Karnes \& D’ Ilio, 1989a).

\section{Myers-Briggs Type Indicator}

Psychological type information, based on Carl Jung's theory of observable differences in mental functioning, is provided by the Myers-Briggs Type Indicator (MBTI) (Myers \& McCaulley, 1985). People create their "type" through the exercise of their individual preferences. Type theory provides a model for understanding the nature of differences among leaders (McCaulley, et al., 1990).

Each individual has a predisposed preference for one of the bipolar attitudes (Extroversion/Introversion, Judging/Perceiving) and functions (Sensing/Intuition, Thinking/Feeling). The MBTI provides an interpretation of type as it relates to how an individual best perceives and processes information and how that individual prefers to interact socially and behaviorally with others. An individual's psychological type is the combination of the two attitudes and functions the individual prefers; therefore, all eight preferences are combined in all possible ways, with 16 types resulting.

Approximately 45 to 60 minutes are needed to administer the 166-item measure. The instrument was designed and standardized to be a self-rating instrument for adolescents and adults. Internal consistency and reliability estimates for con- tinuous scores and dichotomies on the MBTI were calculated with the Spearman-Brown Formula, and they show consistency over time. Construct validity for the MBTI was calculated using product-moment correlations of MBTI continuous scores with scales of personality, interest, and academic tests. These and other data are reported in the manual (Myers \& McCaulley, 1985).

\section{Murphy-Meisgeier Type Indicator for Children}

Also based on Jung's theory of psychological type, the Murphy-Meisgeier Type Indicator for Children (MMTIC) was developed by Meisgeier and Murphy, 1987. This 70-item instrument, designed for students in grades 2 through 8 was constructed to measure the same four preference scales as the MBTI. A total of 4,136 students in grades 2 through 8 were included in the standardization process. A phi correlation coefficient was calculated between each item and scale. Chronbach's Alpha was also calculated for each item. The correlation between every item and its scale was significant at the .0001 level. The internal consistency reliability calculations of the preference scores were estimated using a split-half procedure on the discriminant function scores. Estimates of concurrent and content validity also were established. These and other data are reported in the manual.

\section{Gifted Education Scale}

Designed for students in grades kindergarten through 12 , the Gifted Education Scale contains 48 items covering five areas of giftedness in the 1987 federal definition: intellectual ability, creativity, specific academic aptitude, leadership, and performing and visual arts ability (McCarney, 1987). Constructed for the teacher to rate students on a 5-point scale, the leadership score is derived from 10 of the 48 items. It was nationally standardized on 2,276 students across the United States and can be administered easily in approximately 20 minutes.

\section{Student Talent and Risk Profile}

The Student Talent and Risk (STAR) Profile (Institute for Behavioral Research in Creativity, 1990) is based on Form $\mathrm{U}$ of the Biographical Inventory, which was developed in 1976. The STAR provides seven performance measures: academic performance, creativity, artistic potential, leadership, emotional maturity, educational orientation, and at risk. The student is to respond to each of the 150 items based on the answer that is perceived to be most like himself. The generated computer feedback provides analysis on each student in the seven performance areas and on the group as a whole by percentile scores. Extensive norming data, including validity, reliability, and research studies, are provided in the technical manual. 


\section{Khatena-Morse Multitalent Perception Inventory}

The Khatena-Morse Multitalent Perception Inventory (KMMPT) provides, for students in grades 4 through 12, a self-rating scale in the areas of artistry, musical ability, creative imagination, initiative, and leadership (Khatena \& Morse, 1994). The two forms of the instrument, A and B, contain four and six items in leadership, respectively. The standardization data, including extensive information on validity and reliability, are contained in the technical manual.

\section{Leadership: A Skill and Behavior Scale}

Leadership: A Skill and Behavior Scale, developed by Sisk, is a self-rating instrument (Sisk \& Rosselli, 1987). It contains the areas of positive self-concept, communication skills, decision-making skills, problem-solving skills, group dynamics skills, organizing, planning skills, implementing skills, and discerning opportunities. The students use the following rating scale: never, seldom, sometimes, often, and always. Validity and reliability data are not provided.

\section{Eby Gifted Behavior Index}

The Eby Gifted Behavior Index (Eby, 1989) contains seven checklists, six of which identify the behavioral processes of elementary and secondary school gifted youth in various talent fields: verbal, math/science/problem solving, musical, visual/ spatial, social/leadership, and mechanical/technical/inventiveness. The additional checklist was developed to provide criteria for rating original student products. Items on the Social/Leadership Checklist cover perceptiveness, active interaction with the environment, reflectiveness, persistence, independence, goal orientation, originality, productivity, selfevaluation, and the effective communication of ideas.

A five-point Likert-type rating format on the Social/Leadership Checklist is provided for the teacher. The responses are "evidence of the behavior is shown rarely or never in social activities" to "evidence of the behavior is shown consistently in most social activities." Validity and reliability studies on the Social/Leadership Checklist are reported in the manual.

\section{LEADERSHIP INSTRUCTIONAL PROGRAMS AND MATERIALS}

Leadership Skills Development Program (Karnes \& Chauvin, 1985b) emphasizes the acquisition and application of the necessary leadership concepts and skills based on those identified as necessary to function as an adult leader in society. Major components of the diagnostic/prescriptive program are the Leadership Skills Inventory (LSI), the Leadership Skills Inventory Profile Sheet, the Leadership Skills Inventory Activities Manual, and the Leadership Skills Inventory Administration Manual. Nine subscales constitute the LSI: Funda- mentals of Leadership, Written Communication, Speech Communication, Values Clarification, Decision Making, Group Dynamics, Problem Solving, Personal Development, and Planning. Eight samples of students in grades 4 through junior college in seven states were included in the standardization. The processes used to determine content validity and the internal consistency reliability data, using the SpearmanBrown formula (.80-.93) and the Kuder-Richardson formula (.78-.90) for each of the individual samples and for the total sample, are reported in the manual (Karnes \& Chauvin, 1985c). Criterion and content validity studies have been conducted (Karnes \& D’Ilio, 1988a, 1988b).

Upon entering the program, the students are administered the LSI, a self-rating and self-scoring instrument. After they complete the inventory, the students plot their scores on the Leadership Skills Inventory Profile Sheet, which graphically depicts their strengths and weaknesses in leadership concepts and skills on the nine subscales. The concepts and skills that have been acquired and those in need of strengthening are apparent immediately. This information provides the teacher with the necessary data to assist the student in planning the appropriate instructional activities for every item on the LSI. One or more instructional strategies are provided in the Leadership Skills Inventory Activities Manual (Karnes \& Chauvin, 1985b). The teacher does not have to incorporate all the activities in the manual, just those that will provide the improvement necessary to become an effective leader based on the student's self-perceived strengths and weaknesses. Many of the strategies utilize group discussions, simulations, and role-playing activities as primary vehicles for learning, and they are student-centered rather than teacher-directed.

Crucial to the program is to apply the acquired leadership concepts and skills, which is facilitated by developing and implementing a "Plan for Leadership." After completing the instructional component, the students each identify an area in which they may initiate something new or change an already existing area of need or change in their school, community, or religious affiliation. The plan must have two major purposes:

1. To bring about desirable changes in others' behavior

2. To solve a major problem or to effect major improvements.

Within the student's abilities the plan should be realistic, well sequenced, and comprehensive. Components of the plan to be written by the student include the overall goal with accompanying objectives, activities, resources, timelines, and methods for evaluation. Each plan developed is presented in class for peer review. The types of plans prepared by male and female students for the school, community, and religious affiliation, and the numbers of plans developed during each year of the program were described, and 
an example of a completed plan was presented by Karnes and Meriweather (1989).

The instrument and the materials form the basis of the Leadership Studies Program, a one-week summer residential experience, which has been validated (Karnes, Meriweather, \& D'Ilio, 1987). The statistical analysis of the data collected in the programs indicates pre/post assessment gains to be significant $(\mathrm{p}=.01)$ (Karnes, Meriweather, \& D'Ilio, 1987). Additional support for the program is given by the students and their parents and by leaders from the community and university who have assisted with various aspects.

The program has application for public, private, and parochial schools. After careful analysis of all the program components, including the nine instructional areas necessary for being a leader and the plan for leadership, teachers and administrative decisionmakers and community leaders can readily select the format of the program appropriate for their school and town. It may be an ongoing component of a resource program or pull out enrichment program conducted as a separate class at the junior or senior high school level, or the appropriate components may be included in English, speech, social studies, and other academic courses. Mentorship and internship provisions for growth in leadership skills also should be made readily available to students after they complete the instructional activities.

Another approach to examining leadership in youth is the Leadership Strengths Indicator (Ellis, 1990), a 40-item selfreport questionnaire designed to obtain students' evaluations of their leadership traits and abilities. The indicator yields eight cluster scores and an overall total leadership score. The eight clusters contain two to six items within the following areas: Enjoys Group Activities, Key Individual in Group Activities, High-Level Participator in Group Activities, Journalistic, Sympathetic, Confident, Courageous, Conscientious, and Self-Confident. The rating scale contains the response choices of: excellent, very good, better than most, okay, not so good. The indicator is intended to be a discussion starter for guidance and leadership development classes designed for students in grades 6 through 12. Psychometric properties including validity and reliability are reported in the manual.

The Leadership Training Model for development of leadership in gifted youth was designed by Parker (1983). The areas of cognition, interpersonal, communication, problem solving, and decision making constitute the model. The component of cognition includes exploration, specialization, investigative skill training, and research. Interpersonal communication contains self-realization, empathy, cooperation, and conflict resolution. Problem solving involves problem perception and definition, incubation, creative thinking, analysis, evaluation, and implementation. In the area of decision making are independence, self-confidence, responsibility, task commitment, and moral strength. Several activi- ties are offered for each of the four components of the model (Parker, 1989).

Commercially prepared instructional materials for teaching leadership have been available for nearly two decades. Magoon and Jellen (1980) designed 25 strategies for developing leadership, to assist students to become future leaders by acquiring the skills of leading. The materials offer instructional assistance including a checklist for committee work, a group observation scale, and a listing of references.

House (1980) provided teachers with the Leadership Series, containing six instructional units in analyzing leadership, group skills, self-esteem, communication skills, values and goal setting, and social responsibility. Each unit contains 30 instructional activities based on Bloom's taxonomy of educational objectives with emphasis on the higher levels of thinking: analysis, synthesis, and evaluation. The worksheets provided are reproducible.

Gallagher (1982) developed a curriculum unit on leadership, for upper elementary and junior high school gifted youth. Teachers of the gifted and content specialists worked to design the instructional lessons, which had three specific objectives:

1. To illustrate a particular leadership concept

2. To provide for opportunities for the students to understand and internalize the concepts

3. To develop the student's higher level thinking skills.

Three types of leaders were highlighted in the lesson plans: traditional, legal-rational, and charismatic. The activities in each lesson also are grouped at three levels: awareness, instructional, and extension. These were field-tested in a pilot project. The materials include reproducibles for student use. An annotated bibliography on leadership and evaluation forms for students and parents are provided for the teacher.

Roets (1986a) designed an instructional program for students ages 8-18, titled Leadership: A Skills Training Program. The four themes with instructional activities are: people of achievement, language of leadership, project planning, and debate and discussion. Suggested readings for young people, both fiction and nonfiction, are provided, as is a listing of readings for adults.

Several books directed to elementary and secondary school youth and teachers have been published. Each contains many instructional activities for leadership training. The goals of the leadership materials presented in the book, Leadership Education: Developing Skills for Youth (Richardson \& Feldhusen, 1987), which had been developed previously by Feldhusen, Hynes, and Richardson (1977) with a grant in vocational-technical education, are to develop the student's social skills of leadership. The 11 chapters include an introduction to leadership, outcomes of leadership education, personal characteristics of effective leaders, skills of a group leader, communica- 
tion skills for leaders, leadership skills for group members, developing group goals, planning group activities, committee organization, parliamentary procedure skills, and leadership and special abilities. The evaluation results on use of the materials in the summer leadership program with secondary gifted youth have been positive (Feldhusen \& Kennedy, 1986).

A guide developed to help clarify the meaning of leaders and leadership written by Sisk and Shallcross (1986) is Leadership: Making Things Happen. The book is divided into 10 chapters, each dealing with the skills of leadership. They are: What is Leadership?; Self Understanding: Intuitive Powers; Visual Imagery; Communication; Motivation; Creative Problem-Solving Process; Futuristics; Women in Leadership Positions; and Learning Styles. The activities in each chapter may be used in a wide variety of instructional situations within schools.

Sisk and Rosselli (1987) co-authored the book, Leadership: A Special Kind of Giftedness, to assist in understanding the concepts of leadership and in applying current theories to personal lives and teaching. The five parts of the book emphasize the definition of leadership, the theories, a model for planning and developing leadership training activities, a succinct summary of teaching/learning models, and a discussion on issues and trends in leadership. The four elements of the model developed by Sisk are: characteristics of gifted leadership, selected teaching strategies, teaching/learning models, and key concepts. The book has 20 lessons for teachers and instructors.

Outstanding leadership stories of girls are contained in the book, Girls and Young Women Leading the Way (Karnes \& Bean, 1993). Twenty biographies of girls from elementary school through college are provided as role-models for leadership. Each story contains personal information, followed by a detailed overview of their leadership accomplishments. Following each are questions to challenge the reader to leadership and a listing of appropriate agencies/organizations from which to receive more information. Quotations from nationally known female leaders provide motivation and inspiration. Suggestions for actions to record in a leadership notebook are given, and an extensive reading list on female leaders for kindergartners to young adults is provided.

A book for young leaders ages 8 through 18 contains guidance and advice about moving into leadership positions in the home, school, and community (Karnes \& Bean, 1995). The book, Leadership for Students: A Practical Guide, contains chapters on defining leadership, assessing yourself as a leader, opportunities and training for leadership, influence and encouragement from others, great leaders, and advice to others. The book was designed to be interactive through use of a "leadership action journal," which provides the opportunity for students to record their thoughts and actions pertaining to leaders and leadership. Stories of young leaders offer examples of peers and how they became leaders. The book also features a listing of resources and addresses on leadership opportunities.

\section{INCORPORATING LEADERSHIP CONCEPTS AND SKILLS}

Without more deliberate approaches to youth leadership, input from parents, school personnel, and adult leaders in communities across the nation, only a few students are likely to emerge as leaders, and the world will continue the cry for more effective leaders. The goal of cultivating young leaders is of such critical importance to the individual and to society that it should be made an integral part of school and community programs for youth.

Although schools do provide some opportunities for leadership development through student government, clubs, class officers, and athletics, these experiences are helpful to only a selected few. A more broad-based, expanded curriculum should be considered.

Many approaches could help to prepare young people for leadership roles. Preschool and early elementary-aged students should be encouraged to develop self-understanding, social skills, problem-solving skills, and conflict resolution skills. Teachers may use modeling, creative drama, group discussions, collaborative work, and group play to plant the seeds of early leadership development.

Instructional units on leadership should be taught at each grade level in resource rooms for the gifted. The units could include activities on developing the self as a leader, the study of great leaders and of the concept of leadership and related issues such as ethical dimensions of leadership, theories and styles of leadership, governmental leadership, leadership in the community, leadership and futurism, and so on.

Secondary schools should offer structured courses on leadership for which credit may be granted. Within these courses opportunities should be provided for students to assess their own leadership potential, develop plans for leadership to be implemented in schools, communities, and religious organizations, and to examine issues and areas of interest to which leadership experiences could be applied.

Other options for leadership development may be provided through mentorships and internships. These real-life experiences allow community and business/industry leaders to collaborate with the schools for the common purpose of developing young leaders. Pairing adult leaders with students interested in maximizing their leadership potential has proven to be a positive practice for students and adult leaders alike. Establishing such connections can result in the development of healthier communities, businesses, and industries, as well as produce more effective student and adult leaders.

An alternative approach to specially designed units, courses of study, and mentorships/internships is to incorporate the 
thread of leadership across all curricular and extracurricular activities. The goal of this strategy would be to enable each student to realize his or her potential for leadership. The success of this approach is contingent upon the total support and commitment of all educators, the willingness of all involved to explore leadership connections across all disciplines, and the willingness to seek opportunities for leadership development in every dimension of school life.

Outside of school, young people have an array of choices for leadership opportunities. Youth leadership conferences, seminars, and weekend and summer residential programs are offered through colleges and universities, civic organizations, and business and industries across the nation. Interested parents and students should actively pursue all avenues. The responsibility of enhancing individual leadership potential lies within each of us, but it is the charge of all institutions-families, schools and universities, communities, and religious affiliations - to enrich and advance our society through the intentional process of developing young leaders.

\section{FUTURE DIRECTIONS}

Although leadership research for adults has been steady over the years, more expansive work is needed. Some researchers suggest the need to consider various levels or stages of leadership (Clark \& Clark, 1990). Future research also must address the issues of leadership toward outcomes and leader effectiveness (Clark \& Clark, 1994). More attention to the moral/ethical dimensions of leadership is clear (Clark \& Clark, 1990; Gardner, 1990). A more proactive approach to leadership is supported by recognition of the need for more research on the leadership development of youth (Clark \& Clark, 1994; Gardner, 1990).

To ensure a cadre of leaders for the next century, leadership programs should be developed and validated for preschool, elementary, and secondary school levels. Research studies should be conducted to determine the effects of variables such as instructional strategies, personality, moral development, intellectual/academics level, family environment, and birth order.

\section{REFERENCES}

Abel, T., \& Karnes, F. A. (1993). Self-perceived strengths in leadership abilities between suburban and rural gifted students using the Leadership Strengths Indicator. Psychological Reports, 73, 687-690.

Addison, L. (1985). Leadership skills among the gifted and talented. (1985 Digest, ERIC Clearinghouse, National Institution of Education, ERIC Document Reproduction Service No. ED 262 511)

Alvino, J. (1989). Psychological type: Implications for gifted. Gifted Children Monthly, 10(4), 1-2, 23.

Argulewicz, E. W., Elliott, S. W., \& Hall, R. (1982). Comparison of behavioral ratings of Anglo-American and Mexican-American gifted children. Psychology in the Schools, 19, 469-472.
Barr, L., \& Barr, N. (1989). The leadership equation. Austin, TX: Eakin Press.

Bass, B. M. (1981). Stogdill's handbook of leadership: A survey of theory and research. New York: Free Press.

Bennett, W. J. (1986). What works: Research about teaching and learning. Washington, DC: U. S. Department of Education.

Bennis, W. G., \& Nanus, B. (1985). Leaders: The strategies for taking charge. New York: Harper \& Row.

Black, J. D. (1984). Leadership: A new model particularly applicable to gifted youth. (ERIC Document Reproduction Service No. ED 253 990)

Blake, R. R., \& Mouton, J. S. (1985). The managerial grid III. Houston: Gulf Publishing.

Burke, J. P., Harworth, C. E., Ware, W. B. (1982). Scale for rating behavioral characteristics of superior students: An investigation of factor structure. Journal of Special Education, 16(4), 477-485.

Buros Institute of Mental Measurements. (1985). Ninth Mental Measurement Yearbook (James V. Mitchel, Ed.). Lincoln: University of Nebraska Press.

Calder, B. J. (1977). An attribution theory of leadership. In B. M. Staw \& G. R. Salancik (Eds.), New direction in organizational behavior. Chicago: St. Clair Press.

Campbell, D., \& Velsor, E. V. (1985). The use of personality measures in the leadership development program. Greensboro, NC: Center for Creative Leadership.

Cattell, R. B., Cattell, M. D., \& Johns, E. F. (1984). Manual and norms for the High School Personality Questionnaire. Champaign, IL: Institute for Personality \& Ability Testing.

Chauvin, J. C., \& Karnes, F. A. (1983). A leadership profile of secondary gifted students. Psychological Reports, 53, 1259-1262.

Clark, K. E., \& Clark, M. B. (1990). Measures of leadership. West Orange, NJ: Leadership Library of America.

Clark, K. E., \& Clark, M. B. (1994). Choosing to lead. Charlotte, NC: Iron Gate Press.

Conradie, S. (1984). The identification of leadership potential. In J. Cawood et al. (Eds.), Climbing the ladder to leadership: A panel discussion. Paper presented at international conference on education for the gifted, Ingenium 2000, Stellenbosch, South Africa. (ERIC Document Reproduction Service No. ED 292228 )

D'Ilio, V. R., \& Karnes, F. A. (1992). Student leaders and their parents' perceptions of social skills. Perceptual \& Motor Skills, 74, 863-866.

Eby, J. W. (1989). Eby gifted behavior index (Administration manual). East Aurora, NY: D.O.K.

Elliott, S. N., \& Argulewicz, E. W. (1983). Use of a behavior rating scale to aid in identification of developmentally and culturally different gifted children. Journal of Psychoeducational Assessment, 1(2), 179-186.

Ellis, J. L. (1990) Leadership strengths indicator: A self-report leadership analysis instrument for adolescents. Monroe, NY: Trillium Press.

Feldhusen, J. F., Hynes, K., \& Richardson, W. B. (1977). Curriculum materials for vocational youth organizations. Clearinghouse, 50, 224-226.

Feldhusen, J., \& Kennedy, D. (1986). Leadership training for gifted and talented youth. Leadership Network Newsletter, 1(2), 1-2.

Feldhusen, J. F., \& Kennedy, D. M. (1988). Preparing gifted youth for leadership roles in a rapidly changing society. Roeper Review, 10(4), 226-230.

Fiedler, F. E. (1961). Leadership and leadership effectiveness traits. In L. Petrullo \& B. M. Bass (Eds.), Leadership and interpersonal behavior (pp. 179-186). New York: Holt. 
Florey, J. E., \& Dorf, J. H. (1986). Leadership skills for gifted middle school students. (ERIC Document Reproduction Service No. ED 273 404)

Foster, W. H., \& Silverman, L. (1988). Leadership curriculum for the gifted. In J. VanTassel-Baska, J. Feldhusen, K. Seeley, G. Wheatley, L. Silverman, \& W. Foster (Eds.), Comprehensive curriculum for gifted learners (pp. 356-360). Boston: Allyn \& Bacon.

Friedman, P. G., Friedman, R. J., \& Van Dyke, M. (1984). Identifying the leadership gifted: Self, peer, or teacher nominations. Roeper Review, 7(2),91-94.

Gallagher, J. J. (1982). A leadership unit. New York: Trillium Press.

Galton, F. (1869). Hereditary genius: An inquiry into its laws and consequences. London: Macmillan. (paperback edition by Meridan Books, New York, 1962)

Gardner, J. W. (1990). On leadership. New York: Free Press.

Hartman, R. K. (1969). Teachers' identification of student leaders. Unpublished paper, University of Connecticut, Storrs.

Hersey, P., \& Blanchard, K. H. (1982). Leadership style: Attitudes and behaviors. Training \& Development Journal, 36(5), 50-52.

Hollander, E. P., \& Offerman ${ }_{\odot}$ L. (1990). Power and leadership in organizations: Relationships in transition. In K. E. Clark \& M. B. Clark (Eds.), Measures of leadership. West Orange, NJ: Leadership Library of America.

Hollingworth, L. S. (1926). Gifted children: Their nature and nurture. New York: Macmillan.

House, C. (1980). The leadership series. Coeur d'Alene, ID: Listos. Institute for Behavioral Research in Creativity. (1990). Student talent and risk profile. Salt Lake City: Institute for Behavioral Research in Creativity.

Jacobs, T. O. (1970). Leadership and exchange in formal organizations. Alexandria, VA: Human Resources Research Organization.

Johns, E. F. (1984). The relationship of personality and achievement to creativity and leadership behavior. In R. B. Cattell, M. D. Cattell, \& E. Johns (Eds.), Manual and norms for the High School Personality Questionnaire. Champaign, IL: Institute for Personality and Ability Testing.

Karnes, F. A., \& Bean, S. M. (1993). Girls and young women leading the way. Minneapolis: Free Sprit.

Karnes, F. A., \& Bean, S. M. (1995). Leadership for students: A practical guide. Waco, TX: Prufrock Press.

Karnes, F. A., Bean, S. M., \& McGinnis, C. (1994/1995). Perceptions of leadership held by young females. Journal of Secondary Gifted Education, 6(2) 113-119.

Karnes, F. A., \& Chauvin, J. C. (1985a). Leadership skills inventory. East Aurora, NY: D.O.K.

Karnes, F. A., \& Chauvin, J. C. (1985b). Leadership skills inventory activities manual. East Aurora, NY: D.O.K.

Karnes, F. A., \& Chauvin, J. C. (1985c). Leadership skills inventory technical manual. East Aurora, NY: D.O.K.

Karnes, F. A., Chauvin, J. C., \& Trant, T. J. (1984). Leadership profiles as determined by the HSPQ of students identified as intellectually gifted. Roeper Review, 7(1), 46-48.

Karnes, F. A., Chauvin, J. C., \& Trant, T. J. (1985). Validity of the leadership potential score of the High School Personality Questionnaire with talented students. Perceptual \& Motor Skills, 61, 163-166.

Karnes, F. A., Deason, D. M., \& D'Illio, V. (1993). Leadership skills and self-actualization of school-age children. Psychological Reports, 73, 861-862.

Karnes, F. A., \& D’Ilio, V. (1988a). Assessment of concurrent validity of the Leadership Skills Inventory with gifted students and their teachers. Perceptual \& Motor Skills, 66, 59-62.
Karnes, F. A., \& D'Ilio, V. (1988b). Assessment of criterion-related validity of the Leadership Skills Inventory. Psychological Reports, 62, 263-267.

Karnes, F. A., \& D’Ilio, V. (1989a). Leadership positions and sexrole stereotyping among gifted students. Gifted Child Quarterly, 33(2), 76-78.

Karnes, F. A., \& D'Ilio, V. (1989b). Personality characteristics of student leaders. Psychological Reports, 64, 1125-1126.

Karnes, F. A., \& D'Ilio, V. R. (1990). Sex-role stereotyping of leadership positions by student leaders. Perceptual \& Motor Skills, 70, 335-338.

Karnes, F. A., \& McGinnis, C. (1995). Looking for leadership. Gifted Child Today, 18(1), 30-35.

Karnes, F. A., \& Meriweather, S. (1989). Developing and implementing a plan for leadership: An integral component for success as a leader. Roeper Review, 11(4), 214-217.

Karnes, F. A., \& Meriweather-Bean, S. (1991). Leadership and gifted adolescents. In M. Bireley \& J. Genshaft (Eds.), Understanding the gifted adolescent: Educational, developmental, and multicultural issues (pp. 122-138). New York: Teachers College Press.

Karnes, F. A., Meriweather, S., \& D'Ilio, V. (1987). The effectiveness of the Leadership Studies Program. Roeper Review, 9(4), 238-241.

Khatena, J., \& Morse, D. T. (1994). Khatena-Morse Multi-talent Perception Inventory. Binsonville, IL: Scholastic Testing Service.

Lawrence, G. (1982). People types and tiger stripes: A practical guide to learning styles. Gainesville, FL.: Center for the Applications of Psychological Type.

Lindsay, B. (1988). A lamp for Diogenes: Leadership giftedness and moral education. Roeper Review, 1(1),8-11.

Lord, R. G., De Vader, C. L., \& Alliger, G. M. (1986). A meta-analysis of the relation between personality traits and leadership perceptions: An application of validity generalization procedures. Journal of Applied Psychology, 71, 402-409.

Magoon, R. A., \& Jellen, H. G. (1980). Leadership development: Democracy in action. Poquoson, VA: Human Development Press.

McCarney, S. B. (1987). Gifted evaluation scale. Columbus, MO: Hawthorne Educational Services.

McCaulley, M. H., \& the staff of the Center for Applications of Psychological Type. (1990). The Myers-Briggs Type Indicator and leadership. In K. E. Clark \& M. B. Clark (Eds.), Measures of Leadership. New York: Center for Creative Leadership.

McNamara, J. F., Haensly, P. A., Lupkowski, A. E., \& Edlind, E. P. (1985). The role of extracurricular activities in high school education. Paper presented at annual convention of National Association for Gifted Children, Denver, CO. (Report prepared at Gifted and Talented Institute, Texas A \& M University, College Station, TX)

Meisgeier, C., \& Murphy, E. (1987). Murphy-Meisgeier type indicator for children. Palo Alto, CA: Consulting Psychologists Press.

Meriweather, S. (1989). A study of leadership potential in middle school gifted students. Unpublished doctoral dissertation, University of Southern Mississippi, Hattiesburg.

Meriweather, S., \& Karnes, F. A. (1989). Toward the twenty-first century; Students' views on leadership. Gifted Child Today, 12(2), $40-43$.

Mumford, E. (1909). The origins of leadership. Chicago: University of Chicago Press.

Murphy, A. J. (1941). A study of the leadership process. American Sociological Review, 6, 674-687. 
Myers, I. B., \& McCaulley, M. (1985). Manual: A guide to the development and use of the Myers-Briggs Type Indicator. Palo Alto, CA: Consulting Psychologists Press.

Myers, I. B., \& Myers, P. B. (1980). Gifts differing. Palo Alto, CA: Consulting Psychologists Press.

Myers, M. R., Slavin, M. J., \& Southern, W. T. (1990). Emergence and maintenance of leadership among gifted students in group problem solving. Roeper Review, 12(4), 256-260.

Olivero, J. L. (1977). Leading leaders. In A. H. Passow (Ed.), A new generation of leadership. Ventura, CA: Ventura County Superintendent of Schools.

Parker, J. P. (1983). The Leadership training model: Integrated curriculum for the gifted. Gifted Child Today, 29, 8-13.

Parker, J. P. (1989), Instructional strategies for teaching the gifted. Boston: Allyn \& Bacon.

Person, H. S. (1928). Leadership as a response to environment. Education Records (Supplement No. 6) 9, 10-21.

Plowman, P. D. (1981). Training extraordinary leaders. Roeper Review, 3, 13-16.

Ramey, D. A. (1991). Gifted leadership. Roeper Review, 14(1), 16-19.

Renzulli, J. S., Smith, F. H., White, A. J., Callahan, C. M., \& Hartman, R. K. (1976). Scales for rating the behavioral characteristics of superior students (SRBCSS). Wethersfield, CT: Creative Learning Press.

Richardson, W. B., \& Feldhusen, J. F. (1987). Leadership education: Developing skills for youth. New York: Trillium.

Riley, T. L., \& Karnes, F. A. (1994b). A leadership profile of disadvantaged youth based on Leadership Strengths Indicator. Psychological Reports, 74, 815-818.

Riley, T. R., \& Karnes, F. A. (1994a). Intellectually gifted elementary students' perceptions of leadership. Perceptual and Motor Skills, 79, 47-50.

Roets, L. S. (1986a). Leadership: A Skills Training Program. New Sharon, IA: Leadership Publications.
Roets, L. (1986b). Roets rating scale for leadership. Des Moines, IA: Leadership Publishers.

Rush, M. C., \& Thomas, J. C., \& Lord, R. G. (1977). Implicit leadership theory: A potential threat to the internal validity of leader behavior questionnaires. Organizational Behavior and Human Performance, 20, 93-110.

Schakel, L. (1984). Investigation of the leadership abilities of intellectually gifted students. Unpublished dissertation, University of South Florida, Tampa.

Schatz, E. M. (1981). Development of an instrument to measure selfactualizing growth in adolescents. Unpublished doctoral dissertation, University of Wisconsin.

Schriesheim, C. A., Tolliver, J. M., \& Behling, O. C. (1984). Leadership theory: Some implications for managers. In W. E. Rosenbach \& R. L. Taylor (Eds.), Contemporary issues in leadership. Boulder, CO: Westview Press.

Sisk, D. A. (1984). Leadership as it relates to gifted education. Gifted International, 2(2), 130-148.

Sisk, D. A., \& Rosselli, H. C. (1987). Leadership: A special kind of giftedness. New York: Trillium.

Sisk, D. A., \& Shallcross, D. J. (1986). Leadership: Making things happen. Buffalo, NY: Bearly Limited.

Smith, D. L., \& Smith, L., \& Barnette, J. (1991). Exploring the development of leadership giftedness. Roeper Review, 14(1), 7-12.

Stogdill, R. M. (1974). Handbook of leadership. New York: Free Press.

Terman, L. M. (1925). Genetic study of genius: Vol. 1. Mental and physical traits of a thousand gifted children. Stanford, CA: Stanford University Press.

Vroom, V., \& Yetton, P. W. (1974). Leadership and decision-making. New York: Wiley.

Yammarino, F. J., \& Bass, B. M. (1990). Long-term forecasting of transformational leadership and its effect among naval officers: Some preliminary findings. K. E. Clark \& M. B. Clark (Eds.), Measures of leadership (pp. 151-169). West Orange, NJ: Leadership Library of America.

\section{INDEX • Volume 28}

Author Index

Brownell, Mary T. (September 1995)

Cook, Lynne (November 1995)

Deshler, Donald D. (December 1995)

Fisher, Joseph B. (December 1995)

Friend, Marilyn (November 1995)

Johnson, David W. (February 1996)

Johnson, Roger T. (February 1996)

Kameenui, Edward J. (March 1996)

Kauffman, James M. (January 1996)

Pugach, Marleen C. (April 1996)

Pullen, Patricia L. (January 1996)

Putnam, M. Lewis (October 1995)

Schumaker, Jean B. (December 1995)

Simmons, Deborah C. (March 1996)

Smith, Stephen W. (September 1995)

Swanson, H. Lee (May 1996)

Warger, Cynthia L. (April 1996)

\section{Chronological Index of Titles}

Individualized Education Program: Considering the Broad Context of Reform (September 1995)

Crisis Intervention with Adolescents with Learning Disabilities (October 1995)

Co-Teaching: Guidelines for Creating Effective Practices (November 1995)

Searching for Validated Inclusive Practices: A Review of the Literature (December 1995)

Eight Myths About Special Education (January 1996)

Peacemakers: Teaching Students to Resolve Their Own and Schoolmates' Conflicts (February 1996)

A Focus on Curriculum Design: When Children Fail (March 1996)

Curriculum Considerations in an Inclusive Environment (April 1996)

Classification and Dynamic Assessment of Children with Learning Disabilities (May 1996) 